\title{
Finding a Space for Women: The British Medical Association and Women Doctors in Australia, 1880-1939
}

\author{
LOUELLA MCCARTHY * \\ School of Medicine, University of Wollongong, Northfield Avenue, Wollongong, 2522, Australia
}

\begin{abstract}
This paper examines the experiences of women in one professional organisation - the British Medical Association in Australia - during a significant period in the development of such bodies. In doing so it offers an opportunity to consider the relationship between professional societies and the construction of a gendered profession. For the medical profession in particular the time-frame of this study, from the 1880 s to the 1930 s, has been regarded by scholars as especially important. In this period various features of medical professionalism came to prominence: the status and authority of doctors, the processes of formally registering medical credentials, and the scope and cohesiveness of professional associations. Taking the third of these themes, the current paper extends previous analyses by uniting gender with history and medicine as the central point of examination, in order to evaluate the changing and contested positions of women within the profession. In this way we not only demonstrate how the history of professional societies can reveal the diverse beliefs and shifting priorities of their members, but also contribute to explaining the remarkable persistence of gendered differences in the medical profession.
\end{abstract}

Keywords: Gender, Medicine, History, BMA, Profession, 1880s-1930s

\section{Introduction}

Professional societies became a social and cultural force during the nineteenth century, primarily focused on a single discipline or field of work, such as medicine, law or engineering. The scholarly study of these bodies and their impact can be traced back to a similar time, indicating not only the elements of self-promotion that were implicit in the development of professional organisations, but also a long-term fascination with

* Email address for correspondence: louella@uow.edu.au

I would like to thank Professor Anne O'Brien for her earlier insights to this study, Professor Gabrielle Casper, Dr Deb Colville and members of the executive of the Australian Federation for Medical Women for their ongoing support, the three anonymous reviewers and the Editors of Medical History for their helpful comments. My warm thanks to Dr Hamish Graham for his encouragement and advice. 
the very notion of 'profession'. ${ }^{1}$ Intense scholarly scrutiny during the second half of the twentieth century generated debates about the nature and purpose of professions. ${ }^{2}$ For historians the definitions of profession, enmeshed in a web of theoretical constructs woven by social science, raised the question of whether it was valid to apply the same term across different times and contexts. ${ }^{3}$ Yet the themes identified by social scientists retain salience, even where taxonomies do not necessarily correspond: issues such as a professional body's influence on government policy and the distribution of social and cultural authority, through to the pervasive historical issues of class and ethnicity, continue to underpin our histories of professions, not least in medicine. ${ }^{4}$ Professional societies represent a valuable channel through which to examine the meaning and purpose of professionalism, as an embodiment of the aspirations and beliefs of members. ${ }^{5}$

This paper investigates one component of this history, by applying the analytical tool of gender to examine the foundational philosophy and subsequent development of a major professional association, the British Medical Association (BMA) in Australia. The period chosen for this examination, from the 1880s to the 1930s, has been identified by John Harley Warner as formative in the development of medical professionalism. ${ }^{6}$ It thus offers an opportunity to consider how professional societies influenced the construction of a gendered profession. For while the question of gender and professional societies, including those created by the medical profession, has received some valuable investigation, the current paper extends these analyses by uniting history, medicine and gender as the central point of examination. ${ }^{7}$

As far as medicine is concerned, gender had a primary role in the construction of the profession's image, yet the place of women doctors in medical societies - whether as members of the mainstream associations, or of separatist medical women's organisations

${ }^{1}$ Eliot Freidson, 'The Changing Nature of Professional Control', Annual Review of Sociology, 10 (1984), 1-20; A. Batty Shaw, 'The Oldest Medical Societies in Great Britain', Medical History, 12, 3 (1968), 232-44; John C. Burnham, 'How the Idea of Profession Changed the Writing of Medical History', Medical History, (1998), Supplement No.18.

2 Eliot Freidson, 'Theory of Professionalism: Method and Substance', International Review of Sociology, 9, 1 (1999), 117-29; R.M. Schepers, 'Towards Unity and Autonomy: The Belgian Medical Profession in the Nineteenth Century', Medical History, 38, 3 (1994), 237-54.

3 Tracey L. Adams, 'Profession: A Useful Concept for Sociological Analysis?', Canadian Review of Sociology/Revue canadienne de sociologie, 47, 1 (2010), 49-70; Anne Witz, Professions and Patriarchy (London: Routledge, 1992); S.E.D. Shortt, 'Physicians, Science, and Status: Issues in the Professionalization of Anglo-American Medicine in the Nineteenth Century', Medical History, 27, 1 (1983), 51-68; David Coburn, 'Canadian Medicine: Dominance or Proletarianization?', The Milbank Quarterly, 66 (1988), 92-116; Christopher Lawrence, 'Incommunicable Knowledge: Science, Technology and the Clinical Art in Britain 1850-1914', Journal of Contemporary History, 20, 4 (1985), 503-20; Stephen P. Walker, 'Professions and Patriarchy Revisited: Accountancy in England and Wales, 1887-1914', Accounting History Review, 21, 2 (2011), 185-225; Heather Ellis, 'Knowledge, Character and Professionalisation in Nineteenth-Century British Science', History of Education, 43, 6 (2014), 777-92.

${ }^{4}$ Ellis, ibid.; Douglas M. Haynes, 'Policing the Social Boundaries of the American Medical Association, 184770', Journal of the History of Medicine \& Allied Sciences, 60, 2 (2005), 170-95.

5 Jacqueline Jenkinson, 'The Role of Medical Societies in the Rise of the Scottish Medical Profession 1730 1939’, Social History of Medicine, 4, 2 (1991), 253-275: 255.

${ }^{6}$ John Harley Warner, 'The Fielding H. Garrison Lecture: The Aesthetic Grounding of Modern Medicine', Bulletin of the History of Medicine, 88, 1 (2014): 1-47: 1.

${ }^{7}$ Celia Davies, 'The Sociology of Professions and the Profession of Gender', Sociology, 30, 4 (1996), 661-78; Eli Wald, 'Glass Ceilings and Dead Ends: Professional Ideologies, Gender Stereotypes, and the Future of Women Lawyers at Large Law Firms', Fordham Law Review, 78, 5 (2010), 2245-88; Sheila L. Cavanagh, 'The Gender of Professionalism and Occupational Closure: The Management of Tenure-Related Disputes by the Federation of Women Teachers' Associations of Ontario, 1918-1949', Gender and Education, 15, 1 (2003), 39-57. 
- represents a notable omission in the Australian historiography. What place did the BMA offer to women, and how did women's experiences with the BMA reflect, or indeed contribute to, their professional experiences more broadly? By examining women in a mainstream professional society, this paper investigates the beliefs of medical women (and men) about the ways that gender and professionalism interacted, and the attitudinal differences both in place and time during a crucial period of formation and consolidation of the medical profession in Australia. In doing so, the study explores the ways that professional societies normalise as well as transform representations of practitioners and practice.

This work is part of a larger project to investigate the development of women's medical professionalism through the lens of medical societies. This wider study concerns the experiences of medical women with various medical societies in Australia, but here we examine one component of that project by interrogating what has been termed the 'integrationist' route adopted by some medical women. ${ }^{8}$ Briefly stated, integrationism refers to the process by which women medical practitioners sought acceptance within mainstream medicine, reacting against the belief that women practised medicine differently from men.

The present argument is developed in five stages within a roughly chronological framework, starting with an overview of the development of the BMA and its organisation in Australia. Issues surrounding women's admission to the medical profession, and indeed to the BMA, provide the focus for a second section. Towards the end of the nineteenth century, women's acknowledgement as professional colleagues received significant assistance from some influential medical men in both Australia and the United Kingdom, despite the fact that many male doctors remained unconvinced. The third section uses a case study of a women's friendly society in the early twentieth century to dissect the economic imperatives of the BMA in Australia. This serves to highlight the association's unwillingness - or inability - to identify and accept the gendered divisions in society at that time. In the fourth section the discussion moves to an outline of the shifting appeal of BMA membership for Australia's medical women during the formative period in question. This shows how women's involvement in the profession's pre-eminent association waxed and waned in response to a range of impulses and aspirations. That diversity of experience and the pervasiveness of the medical profession's masculine culture in Australia is highlighted in the fifth section, which explores examples from the 1930s. Some medical women thrived in both their professional lives and their wider roles in society; a few of them were even awarded imperial honours. Yet this article concludes by suggesting that gendered assumptions always remained a prominent feature of the BMA's professional culture in Australia - even if that leaves open the question of the extent to which these reflected the views of the medical profession more generally, or were largely a product of Australian society at that time.

\footnotetext{
${ }^{8}$ Ellen More, 'The Blackwell Medical Society and the Professionalization of Women Physicians', Bulletin of the History of Medicine, 61, 4 (1987), 603-28; Louella McCarthy, 'Idealists or Pragmatists? Progressives and Separatists among Australian Medical Women, 1900-1940', Social History of Medicine, 16 (2), 2003, 263-82; Virginia Drachman, Hospital with a Heart: Women Doctors and the Paradox of Separatism at the New England Hospital, 1862-1969 (Ithaca, NY: Cornell University Press, 1984); Eve Fine, 'Separate but Integrated: Bertha Van Hoosen and the Founding of AMWA', Journal of the American Medical Women's Association, 45 (1990), 181-90; Estelle Freedman, 'Separatism as Strategy: Female Institution Building and American Feminism, 18701930', Feminist Studies, 5, 3 (1979), 512-29.
} 


\section{The BMA and the Growth of Professional Societies}

The 1800s can be seen as the century of organised medicine. Most of the national medical societies currently functioning in the West, such as the BMA in the UK, the American Medical Association, or the French medical association were formed during the nineteenth century, and this historical longevity is often portrayed as a sign of prestige. ${ }^{9}$ Indeed for some scholars the medical association was the template from which other professional associations later drew their inspiration. ${ }^{10}$ Yet, as Roy Porter pointed out, this was a period in which doctors' pleas for official recognition and state-sanctioned authority were generally slow to be heeded. ${ }^{11}$ As a consequence the early nineteenth century saw a proliferation of small organisations, often centred on particular localities and regions, or on the leadership of individual doctors. But by the end of the century and in the decades after 1900 many of these bodies disappeared or were supplanted by the emerging national associations.

The story of the BMA's rise to pre-eminence has been quite well rehearsed by scholars. The bare outline traces its evolution from the Provincial Medical and Surgical Association at Worcester in 1832, through its rise via the absorption, displacement or affiliation with other groups, to metamorphose into the peak body of the national profession. ${ }^{12}$ The BMA's development within the UK was in many respects duplicated around the globe. Thus Canada, South Africa, India, Jamaica, New Zealand and the various Australian colonies each saw early domestic organisations formed at local or regional levels, which were later subsumed within or displaced by the BMA through its network of overseas branches. Reflecting the period's colonial expansion, the BMA proudly proclaimed itself in 1885

... an Imperial institution, extending its ramifications to all parts of the Empire and linking together the members of the profession, wherever found, in one body, animated by a common purpose - the advancement of scientific medicine and the social well-being and dignity of its associates. ${ }^{13}$

Yet over the course of the twentieth century the inherent and long-lived tensions between responding to local concerns and maintaining allegiance to the imperial centre ultimately resulted in the waning of the BMA's hold over its branches in the 'dominions'. Canada was the first to make the definitive split in 1927, followed by South Africa in $1945 .{ }^{14}$ Australia and New Zealand retained their affiliation longer, forming their own national bodies only in 1962 (Australian Medical Association) and 1967 (New Zealand Medical Association). ${ }^{15}$

\footnotetext{
9 [Editorial], 'The History of the French Medical Association', British Medical Journal, 1, 3921 (1936), 431.

${ }^{10}$ Harold F. Gosnell and Margaret J. Schmidt, 'Professional Associations', The Annals of the American Academy of Political and Social Science, 179, 1 (1935), 25-33.

${ }^{11}$ Roy Porter, The Greatest Benefit to Mankind: A Medical History of Humanity (London: Harper Collins, 1997), 352.

12 Peter Bartrip, Themselves Writ Large: The British Medical Association (London: BMJ, 1996), 1-2; Jacqueline Jenkinson, Scottish Medical Societies 1731-1939: Their History and Records (Edinburgh University Press, 1993), 79-82.

13 [Leader], 'The B.M.A. and its Colonial Branches', British Medical Journal, II (1885), 882; Terence J. Johnson and Marjorie Caygill, 'The British Medical Association and its Overseas Branches: A Short History', Journal of Imperial and Commonwealth History, 1, 3 (1973), 303-29; Milton J. Lewis, 'Medicine in Colonial Australia, 1788-1900', Medical Journal Australia, 201, 1 Suppl. (2014), S5-S10: S2.

14 'Official Notice', Canadian Medical Association Journal, 1, 1 (1911), 57; Bartrip, op. cit. (note 12), 292; South African Medical Association, 'SAMA's History' (1998) https://www.samedical.org/about-us/history (accessed 10 August 2017).

15 C.J. Ross-Smith, 'The Evolution of a National Medical Association in Australia', Medical Journal of Australia, May 1962, 746; Wellcome Library (London), SA/BMA/A133 (01436), 'Constitution of the Australian Federal Committee: Proposal to Form a Federal Council for Australia, 1912-1947’.
} 
In line with the geographically defined nature of colonial politics more generally, nineteenth-century Australian medical societies tended to form in major cities, usually born of local interests, and often racked by internal factions. As a consequence several were short-lived. ${ }^{16}$ The BMA's path to bridging these local divisions emerged as a result of the agitation by medical men to form local branches in Victoria, South Australia and New South Wales (NSW), all of which were recognised by the BMA as branches in 1880, to be followed by Queensland (1894), Western Australia (1899) and Tasmania (1911). ${ }^{17}$ The impetus for these developments is unclear. It may have been a response to the formation of similar bodies in other parts of the empire. ${ }^{18}$ Alternatively, the development may simply have reflected the propensity of British medical men to take up colonial practice, and in doing so carry with them an attachment to the 'home' association. Certainly 'imperial' rhetoric was strong among the medical profession in late nineteenth-century Australia. Whatever the case, while the early branches of the BMA in Australia had some success in forging a collective identity for doctors - not least through its journal(s), and the Australasian medical congresses - those foundations did not immediately change the characteristic forms of early medical organisation in Australia, and debates around the creation of a national body continued well beyond the period under discussion here. ${ }^{19}$

From the viewpoint of the practitioners, professional association membership could play a number of important roles, most notably in providing opportunities for professional and social advancement. ${ }^{20}$ One benefit of membership of the BMA (New South Wales), for example, was a doctor's concurrent subscription to both the British Medical Journal and the Australasian Medical Gazette (from 1914 the Medical Journal of Australia) from which, according to A.V.M. Anderson in 1921, 'he learns what is going on in the way of research and discovery here and abroad'. ${ }^{21}$ The BMA itself claimed to promote 'the paramount local object of drawing the medical men of a district into friendly co-operation for scientific and other professional purposes'. ${ }^{22}$ Those excluded from professional associations often lamented their lack of contact with fellow professionals, especially, as Felicity Allen put it, the ability 'to discuss difficult cases and exchange opinions' ${ }^{23}$

Historians have highlighted other crucial components of professional societies and their members. Most significant for the context of this paper is the role of the professional body in shaping or reflecting dominant views of those involved in practice: ‘identity creation' for

\footnotetext{
${ }^{16}$ Milton Lewis and Roy MacLeod, 'Medical politics and the professionalisation of medicine in New South Wales, 1850-1901', in Roy MacLeod and Milton Lewis (eds), Disease, Medicine and Empire: Perspectives on Western Medicine and the Experience of European Expansion (London: Routledge, 1988), 69-82; James Gillespie, The Price of Health: Australian Governments and Medical Politics, 1910-1960 (Melbourne: Cambridge University Press, 1991), 95-6.

17 'The British Medical Association and its Australian Branches', Australasian Medical Gazette, I, November (1881), 25-6; Ross-Smith, op. cit. (note 15), 746-8.

18 Bartrip, op. cit. (note 12), 292.

19 'NSW Branch, BMA: Council Minutes', Medical Journal Australia, November (1937), 854; 'Constitution of the Australian Federal Committee', op. cit. (note 15); Ross-Smith, op. cit. (note 15), 746, 748-50; Gillespie, op. cit. (note 16), 95.

${ }^{20}$ Paul Atkinson and Sara Delamont, 'Professions and Powerlessness: Female Marginality in the Learned Professions', Sociological Review, 38, 1 (1990), 101.

21 A.V.M. Anderson, 'Lectures on Medical Ethics', Medical Journal Australia, July (1921), 20-7: 22.

22 BMA Constitutional Committee, Provisional Report, Supplement to British Medical Journal, February (1901), 2.

${ }^{23}$ Felicity Allen, 'Women and the Profession of Medicine', in Heather Gardner (ed.), The Politics of Health: The Australian Experience (Melbourne: Churchill Livingstone, 1995), 332.
} 
medical practitioners. ${ }^{24}$ As Christopher Lawrence pointed out, medical professionalism has meanings specific to time and place. ${ }^{25}$ The culture of the profession was one that took cues from its cultural milieu and thus emphasised those qualities lauded by the culture in which it was embedded. Thus the equation of 'medical professional' with 'man' was commonplace (as A.V.M. Anderson's remarks revealed), but it also transcended linguistic conventions. Despite being 'extremely variegated in its attitudes, goals and standards', as Lawrence explained, the profession was one in which 'only the gentleman, broadly educated, and soundly read in the classics, could be equipped for the practice of medicine' ${ }^{26}$ The culture of the medical profession, in other words, was formed gendered as well as classed.

\section{Medical Women and Professional Societies}

The struggle between the American Medical Association and the American Women's Medical Association during the Sheppard-Towner debates of the 1920s alerted historian Kristin Barker to a particularly fruitful means for investigating gendered differences in the conception of profession. She summarised this technique as looking for 'gender alliances and gender fractures in intra- and inter-professional jurisdictional disputes' ${ }^{27}$ One of the objectives of professional associations is to establish professional boundaries and, as Barker suggested, 'gender within these professions can influence the shape of the boundaries'. ${ }^{28}$ The present investigation reinforces Barker's point. Examining and comparing women's and men's experiences of membership in professional associations - in both their regulatory and social functions - allows us to assess the extent to which 'medical women' were defined as a group, identifiably different from their male colleagues, or whether there were diversities among medical women equivalent to those among medical men.

In the Australian colonies BMA membership was available to women almost simultaneously with the awarding of medical degrees to women. To understand how this happened we need first to consider women's place in the BMA in Britain, although the regional branch structure of the association in Australia also needs to be kept in mind. For while operating as colonial branches, the membership often represented itself in nationalist terms. Nevertheless, joining occurred at the branch, not the national, level. So while New South Wales was the largest and possibly most influential branch of the BMA in Australia, through its control of the Australasian Medical Gazette, each colonial (later state) branch demonstrated these conflicting loyalties between local or national issues and imperial policies. ${ }^{29}$ Some of the impetus for the British association to (re)admit women members came from the lobbying by prominent medical men in Australia - even if their views were by no means widely shared.

\footnotetext{
${ }^{24}$ Delia Gavrus, 'Men of Dreams and Men of Action: Neurologists, Neurosurgeons, and the Performance of Professional Identity, 1920-1950', Bulletin of the History of Medicine, 85, 1 (2011), 57-92.

${ }^{25}$ Christopher Lawrence, 'Incommunicable Knowledge: Science, Technology and the Clinical Art in Britain 1850-1914', Journal of Contemporary History, 20, 4 (1985), 503-20: 503.

26 Ibid., 505.

${ }^{27}$ Kristin Barker, 'Women Physicians and the Gendered System of Professions', Work and Occupations, 25, 2 (1998), 229-49: 231.

${ }^{28}$ Ibid., 229-32.

29 'The British Medical Association and its Australian Branches', Australasian Medical Gazette, I, November (1881), 23.
} 
Women's membership of the BMA in Australia officially began in 1893, just thirteen years after the association's establishment in Australia, and within six months of the change in BMA rules permitting women's membership. As off-shoots of the BMA, the Australian branches were bound by the parent body's rules of association, the fourth of which expressly excluded women from membership. As has been examined by a number of historians, the 'pioneer' British woman doctor, Elizabeth Garrett Anderson, had successfully applied for membership in 1873, but in response to growing unrest among (male) members, a special meeting of the BMA in 1878 carried a motion to forbid any further female applicants. ${ }^{30}$

In consequence women's membership was impossible in any of the BMA's many branches, until the 'Fourth Clause' was rescinded at a special meeting in Nottingham in August 1892. In March 1893 Frances Dick was elected by the NSW branch as the first woman member of the BMA in Australia. ${ }^{31}$ The timing of this 'pioneering' achievement was significant for two reasons. Overseas-trained women doctors had just registered to practise: Emma Constance Stone in Melbourne (Victoria) in 1890, followed in 1892 by Frances Dick (February) and Margaret Corlis (June) in NSW. ${ }^{32}$ Local graduations closely followed these registrations. The University of Melbourne graduated its first two female students - Margaret Whyte and Grace Stone - at the end of 1891, with two more in the subsequent year. ${ }^{33}$ The University of Adelaide (South Australia) graduated its first medical woman, Laura Fowler, in 1892, and the University of Sydney's first two medical women, Iza Coghlan and Grace Robinson, graduated in 1893. ${ }^{34}$ While the Australian branches of the BMA were discrete entities, as part of an international network, each was barred from taking steps independently. Yet discussions over women's admission to the Association were taking place around the country: how these discussions played out provides a useful case-study of the BMA's responses to the 'woman-doctor question'.

Women's admission to the BMA in Australia was first publicly canvassed in the Australasian Medical Gazette in March 1892, some months before the BMA's Nottingham meeting. The Gazette's sympathetic coverage of the issue followed an application for membership of the South Australian branch from Adelaide's first female graduate, Laura

\footnotetext{
30 'Medical Affairs in Edinburgh', British Medical Journal, 1, 680 (1874), 54; 'Letter to the Editor', The Lancet, July (1877), 75; 'University of London: Meeting of Convocation: Debate on the Admission of Women to Degrees', The Lancet, January (1878), 103-6; [Leader], 'The BMA and Unwomanly Women', The Lancet, February (1878), 174-5. 'British Medical Association', British Medical Journal, 1, 1169 (1883), 1028. For an overview see Tara Lamont, 'The Amazon Within: Women in the BMA 100 Years Ago', BMJ, 1305, 6868 (1992), 1529.

31 'The Month', Australasian Medical Gazette, XII, March (1893), 101.

32 Stone was a Melburnian who had trained in the USA: [Editorial], 'Dr E. Constance Stone: First Australian Lady Doctor', Table Talk (1890), 4-5; Heather Sheard, 'Innovators and leaders: from Dr Constance Stone to Dame Annie Jean Macnamara', in Jacqueline Healy (ed.), Strength of Mind: 125 Years of Women in Medicine (Melbourne: University of Melbourne, Medical History Museum, 2013), 25-44: 25. Frances Dick was an Australian who had trained in Britain: 'Royal University of Ireland', British Medical Journal, 23 March (1893), 1153. Margaret Corlis was a Canadian who had trained at Queen's University, Ontario in the brief period of women's acceptance there before they were excluded until 1948! See Julia Cataudella, 'When Women Came to Queen's', Canadian Medical Association Journal, 161, 5 (1999), 575-6.

33 Jane Gunn, introduction in Strength of Mind, ibid., 20.

${ }^{34}$ K.F. Russell, The Melbourne Medical School 1862-1962 (Melbourne: Melbourne University Press, 1977), 74-5; Elma Sandford Morgan, A Short History of Medical Women in Australia (Adelaide: Australian Federation of Medical Women, 1970), 9; Marjorie Hutton Neve, This Mad Folly: The History of Australia's Pioneer Women Doctors (Sydney: Library of Australian History, 1980), 33, 35.
} 
Fowler. ${ }^{35}$ The editorial warmly endorsed the development, and encouraged other branches to address the issue as well:

A rule of the parent society excludes ladies from membership, but the time is now past when such a course can be logically defended, and we think that the Australian branches will do well to conjointly approach the Council in Great Britain, asking its repeal. ${ }^{36}$

Supporting Fowler's application were two influential members of the South Australian profession: Alfred Lendon, the branch secretary, and Joseph Verco. ${ }^{37}$ Together these men argued that, since women had been permitted to graduate as doctors and to register for practice, they should be given equal access to 'the privileges of the fully qualified practitioner', which included membership of the BMA. The branch knew it was unable to make a decision counter to the rules of the parent body, however, so the discussion was limited to 'the abstract question as to whether it was desirable or not to admit women to an equality with ourselves'. Those present then agreed not to vote on the motion immediately, but to survey the views of the branch's members. ${ }^{38}$ In April 1892, Lendon reported that the plebiscite had resulted in 'an absolute majority' in favour of women's admission, and he urged that they should now 'communicate the feeling of the Branch upon this matter to the Council of the Parent Association'. ${ }^{39}$ The Victorian branch's discussions were conducted almost simultaneously and apparently with as little angst. Its motion to admit women 'was carried with only one dissenting voice', and both the Victorian and the South Australian branches then petitioned London to repeal the bar on women's membership. ${ }^{40}$

In July 1892 the BMA's AGM in Nottingham noted: 'The question of the admission of women to the Association was brought into the region of discourse by the action of several of our Colonial Branches... '. ${ }^{41}$ While the British Medical Journal reported the development in a calm and positive manner, the records clearly indicate that the meeting was far from unanimous, and tumultuous discussion ensued. An Extraordinary General Meeting was called, which was held the following month in London. James Usher, an Australian doctor from Ballarat (Victoria) attended this gathering, and added (as he said):

...a few words for the women in Australia. The present causus belli had arisen from the action of the Branches in that part of the world. In Victoria and New South Wales, and he believed in Queensland, unanimous votes had been given in favour of the admission of lady doctors, and the same might be said with regard to India, the Cape, and Canada.... There were some 200 ladies qualified by the British colleges applying for admission into the most powerful combination of medical men in the whole world, and it was only a gracious act to admit them to membership. . . It was enough to know that these ladies were women of talent, courage, and breeding. . . ${ }^{42}$

\footnotetext{
35 'The Question of the Admission of Women to the Membership of the British Medical Association', Australasian Medical Gazette, XI, March (1892), 167. This position contrasted with the Gazette's later discussions about women's place in hospitals. See Louella McCarthy, 'All This Fuss about a Trivial Incident? Women, Hospitals and Medical Work in New South Wales', Women's History Review, 14, 2 (2005), $267-85$.

36 'Question of the Admission of Women', ibid., 167.

${ }^{37}$ Ibid., 164-5. Lendon was then lecturer in forensic medicine and clinical medicine, and later became dean of the faculty at Adelaide in 1896 . Verco had been a key participant in the creation of the Inter-Colonial Medical Congresses, recognised by his presidency of the first gathering in 1887, Inter-Colonial Medical Congress: Transactions of the First Session (Adelaide, 1887).

38 Ibid., 165.

39 'Proceedings of Societies: South Australian Branch of the BMA', Australasian Medical Gazette, April (1892), 181.

40 Sandford Morgan, op. cit. (note 34), 11; 'Question of the Admission of Women', op. cit. (note 35), 164.

41 'The Nottingham Meeting: The Admission of Women', British Medical Journal, 2, 1649 (1892), 317.

42 'British Medical Association: Admission of Women', British Medical Journal, 2, 1652 (1892), 481.
} 
In September 1892, trumpeting that it had long 'advocated the admission of women to the profession', the Australasian Medical Gazette reported 'with great satisfaction' that the BMA Council had indeed revoked the rule. ${ }^{43}$

However, Australian male doctors were more divided than had first appeared on this issue resembling their UK colleagues, which is highlighted by the debates at branch level. In the months preceding the Nottingham decision, both the South Australian and NSW branches revisited the question of women's admission. These debates exposed the depth of some members' antagonism to women, not just as members of their association but also as medical practitioners. The NSW branch's meeting in May agreed to sound out the membership's feelings. At the subsequent gathering on 3 June, the president Thomas Fiaschi reported that 58 of the 85 responses received $(68 \%)$ were in favour of women's membership. ${ }^{44}$ This was comparable with the South Australian plebiscite, where Lendon's 'absolute majority' represented 46 in favour from 75 votes cast (61\% of the membership)..$^{45}$

But if the NSW branch's meetings were (apparently) subdued, the South Australians' were lengthy and heated. The difference seemed to lie at the executive level, for the South Australian leadership was divided. The most vociferous opponent was the branch vicepresident and surgeon, Ben Poulton, supported by two fellow surgeons. One, R. Kendray Archer, apparently objected to having women in the profession at all. It was foolish, he believed, 'to run the risk of upsetting the prosperity and harmony of the society for a lifeless innovation, and for the sake of so small a proportion of eccentric individuals'. Archer elaborated on this unflattering term: 'I think a woman who has braved the horrors of the dissecting room and the disgusting necessities of the post mortem table may, seeing they are so few, be justly termed eccentric'. ${ }^{46}$ Even after the Nottingham rescission Poulton, for his part, continued to oppose the admission of women (and specifically Laura Fowler) to his branch of the BMA. Rejecting Lendon's claims of an 'absolute majority', Poulton insisted the ballot had shown that 'about half the members voting objected'. A special general meeting was needed to debate the whole issue, he argued, because even those members who did 'not oppose the innovation would very much rather the women stayed away'. Poulton stressed the potentially grievous ramifications of accepting women: 'Do not let us initiate a system in the only Medical Society of the place,' he urged, 'which will create coolness and indifference, if it do not breed discontent and cause defection from the ranks. ${ }^{47}$

So, on 17 November 1892 - two months after the rule's repeal - the South Australian branch convened yet another meeting to decide its position on the question of women's membership. In the interval between notification of the ban's rescission and this 'unusually large' meeting, the question of women's admission had 'excited considerable interest and some little feeling' within the branch. ${ }^{48}$ The minutes noted some members' expressions

\footnotetext{
43 'The Admission of Medical Women as Members of the BMA', Australasian Medical Gazette, XI, September (1892), 359.

44 'Proceedings of Societies: NSW Branch', Australasian Medical Gazette, XI, June (1892), 253; 'Proceedings of Societies: NSW Branch', Australasian Medical Gazette, XI, July (1892), 279.

45 'Proceedings of Societies: South Australian Branch', Australasian Medical Gazette, XI, April (1892), 181.

46 Ibid., 181.

47 'Proceedings of Societies: South Australian Branch', Australasian Medical Gazette, XI November (1892), 413.

48 'Proceedings of Societies: South Australian Branch', Australasian Medical Gazette, XI, December (1892), 438.
} 
of reluctance 'to address a mixed audience, or to join in discussion in the presence of the opposite sex'. But the spokesman in favour of women's admission, Edward Stirling - a colleague of Lendon's in the Adelaide medical school and later dean of medicine and president of the branch - suggested that no arguments had been proffered, merely 'sentiments and personal feelings' ${ }^{49}$ Stirling's support was no doubt influential given his prominence, but also not unexpected. As a member of the South Australian Legislative Assembly in 1887, Edward Stirling had tabled a bill to grant South Australian women the vote. ${ }^{50}$ While the colony's women had to wait until 1894 for the franchise, the November meeting of the BMA at least saw the women's 'champions' of their BMA membership carry the day, after the branch had publicly argued the point for almost twelve months. The parallel timing of debates about women's voting rights and their admission to the BMA was by no means unconnected.

These cases indicated that there remained strong pockets of male opposition to women's membership within the Australian medical profession. So why did the majority of BMA branch office-holders in Australia choose to support the idea of women's membership, even to the extent of petitioning London to achieve it? Some medical men were genuinely concerned at the 'sex discrimination' explicit in women's exclusion. In South Australia, Edward Stirling was convinced: the medical profession 'should be in the foremost in intellectual liberality', and so the BMA branch should 'place no disabilities on anyone on account of sex'. ${ }^{51}$ There was also growing adherence to the belief that women doctors were a feature of advancing modernity, and that continuing to exclude them cast a shadow of obsolescence over the profession. At the Nottingham meeting, for example, F.J. Gant highlighted the variety of medical institutions that had agreed to admit women, and chose an interesting metaphor to characterise a notable exception: 'The College of Surgeons, it was true, had not admitted them', Gant was reported as saying, 'but that was rather a slow-going machine, something like the Lord Mayor's Coach, old and rickety'. ${ }^{52}$

Another powerful inducement to admit women was the one presented in Britain by Elizabeth Garrett Anderson herself: money. 'You do not want women to be willing to do any amount of work for the lowest prices', she told the BMA in London when the ban on women's membership was first debated in 1878. 'You do not want them to be insensible to the general pecuniary interests of the profession. ${ }^{53}$ Comparable concerns for self-interest clearly played a role in the subsequent debates about women's readmission. A central concern of professional associations is marking out the boundaries of professional expertise, so even if the association wished to exclude women (as several of its members clearly did), the exigencies of the association's professional boundaries compelled it either to encompass appropriately qualified women, or relinquish those hard-won boundaries altogether. ${ }^{54}$ Women within the association were bound by its rules and could be punished for breaking them - but by leaving them all as 'outsiders' the association could have no control over their actions. In the 1892 rescission debate, as Lamont has argued, the 'fear of an unregulated body of women doctors not bound by any professional ethos'

\footnotetext{
49 Ibid.

${ }^{50}$ Hans Mincham, 'Stirling, Sir Edward Charles (Ted) (1848-1919)', Australian Dictionary of Biography (Canberra: ANU National Centre of Biography, 1976) http://adb.anu.edu.au/biography/stirling-sir-edward-cha rles-ted-939/text7675 (accessed 31 July 2015).

51 Ibid., 438.

52 'British Medical Association: Admission of Women', British Medical Journal, 2, 1652 (1892), 481-2.

${ }^{53}$ Elizabeth Garrett Anderson, 'Forty-Sixth Annual Meeting of the British Medical Association, British Medical Journal, 2, 920 (1878), 253.

${ }^{54}$ Barker, op. cit. (note 27), 229-32. Compare Haynes, op. cit. (note 4).
} 
was a powerful motivation for the BMA to change, despite some males doctors' concern (as the Australasian Medical Gazette put it) about feeling 'handicapped in the discussion of some cases by the presence of ladies'. ${ }^{5}$

\section{Medical Women's Work and the BMA}

Despite the men's heated debates over women's admission to the BMA, Australian women seemed to greet the victory ambivalently. Of the women who graduated from Sydney in the 1890s and registered to practise, less than fifty per cent became members of the BMA. Part of the explanation may have been the annual fee of two guineas ( $22 \mathrm{~s}$.), which could have dissuaded hard-pressed young doctors striving to establish a practice. ${ }^{56}$ Memories of the recent claims about the 'appropriateness' of women's membership might also have led some women to be cautious about the welcome they could expect from the organisation. And, as subsequent events bore out, the BMA remained so overwhelmingly masculine in its culture that it was unable to recognise the structural disadvantages faced by women in the wider society. One example of the BMA's masculine assumptions concerned the Women's Australian Natives' Association (WANA).

Scholarship on the lodges and friendly societies in the history of medicine in Australia and other parts of the British empire has highlighted the essential role they played in providing health care access for many, particularly poorer, people, as well as the fierce contest conducted by the BMA for their control. ${ }^{57}$ Harriett Biffin, a Sydney graduate of 1898, was appointed in 1903 as the lodge doctor to the newly formed WANA, Sydney branch No.1, whose prospectus proclaimed its prime concerns: 'to assist the Women of Australia in every walk of life, by promoting and advancing the interest of the working and professional women of Australia, more particularly those who have entered the Medical Profession'. ${ }^{58}$ This statement acknowledged the obstacles faced by early medical women in establishing and maintaining a practice. ${ }^{59}$ Professional networks and referral patterns were important in setting up a viable private practice, and where these were absent, several medical women (and some men) turned to alternatives such as insurance work and lodge doctoring, or other forms of practice such as salaried positions and asylum work. ${ }^{60}$

Membership figures for the WANA in the first year of its existence are not available, although there were indications that there may have been as many as fifty members by

55 Lamont, op. cit. (note 30), 1531; 'The Admission of Medical Women', op. cit. (note 43), 359.

${ }^{56}$ Mitchell Library, State Library of New South Wales (Sydney), Australian Medical Association [henceforth AMA] Collection, ML Mss 213/97 21/23, BMA Membership Ledgers, Vol. 1, 1891-1901.

57 David Green and Lawrence Cromwell, Mutual Aid or Welfare State: Australia's Friendly Societies (Sydney: Allen \& Unwin, 1984), 101-30; Sue Graham-Taylor, 'Voluntary health insurance: lessons from the past', in P. Winterton and D. Gurry (eds), The Impact of the Past upon the Present: Second National Conference of the Australian Society for the History of Medicine (Perth, WA: ASHM, n.d. [1992]), 70-4; Anne Crichton, Slowly Taking Control? Australian Governments and Health Care Provision, 1788-1988 (Sydney: Allen \& Unwin, 1990), 18-20, 32, 35-6; Ken Inglis, Hospital and Community: A History of the Royal Melbourne Hospital (Melbourne: Melbourne University Press, 1958), 44-5; Jennifer Carlyon, 'New Zealand Friendly Societies, 1842-1941' (unpublished PhD thesis: University of Auckland, 2001).

58 Mitchell Library, 363/W, 'Women's Australian Natives' Association (Registered Under the Friendly Societies Act): A Patriotic, Literary, Mutual Improvement and Sound Benefit Society, to Assist, to Aid, to Relieve' (Sydney, 1903). See also The Australian Star (Sydney), 5 May 1903, 4.

${ }^{59}$ Michael Belgrave, 'A Subtle Containment: Women in New Zealand Medicine, 1893-1941', New Zealand Journal of History, 22, 1 (1988), 44-55; Louella McCarthy, 'Filtered Images: Visions of "Pioneering" Women Doctors in Twentieth-Century Australia', Health \& History, 8, 2 (2006), 91-110.

${ }^{60}$ Louella McCarthy, 'Uncommon Practices: Medical Women in New South Wales, 1885-1939', (unpublished PhD thesis: University of NSW, 2001), 293-300. 
the time of Harriett Biffin's appointment. ${ }^{61}$ As the lodge's policy was designed around recognising women's lower wages, its contribution rates were comparably low, which may have led to a larger membership in time. ${ }^{62}$ Green and Cromwell estimated that contributions to male lodges of the same period ranged from one to two shillings (twelve to twenty-four pence) a week, as a 'family' contribution. ${ }^{63}$ By contrast the WANA's weekly rates began at ten pence for women between the ages of sixteen and twentyfour, rising to one shilling and threepence (fifteen pence) for those aged between fortythree and forty-five. For this subscription, members were offered medical attendance and all medicines, sick-pay on a declining scale beginning at ten shillings a week (after nine months' membership), and a ten-pound funeral allowance. Furthermore, benefits could be extended 'in special cases' to members' children and step-children, as well as to widowed mothers and sisters. In addition to the gender politics that the WANA represented (in which Biffin herself had been an active participant), the lodge's popularity among women would have been seen by Biffin as a valuable means to build up her practice, and thus increase her own chances of professional success.

The principle underlying this lodge was women's restricted earnings in all forms of labour. For the BMA, however, the WANA was fatally associated with the more famous Australian Natives' Association (ANA). ${ }^{64}$ The medical profession had long been antagonistic to the Natives' Association because of its 'patriotic appeal'. ${ }^{65}$ In 1895 William Mullen cautioned the profession that 'of all these friendly societies, the one on which we must look with the greatest concern is the ANA', not least because as a 'patriotic' society its attraction was great, 'even to the wealthy'. ${ }^{66}$ In 1900, 'Anti-Humbug' condemned the ANA as a 'medical sweating society' of 'economic patriots', and applauded the BMA for 'taking action' against them. ${ }^{67}$ The women's lodge certainly replicated broad outlines of the ANA's interests, particularly in seeking to 'encourage and promote a patriotic spirit, a love of country, and sympathy for all that is pure and good', and by insisting on 'Australasian birth' as a membership qualification. ${ }^{68}$ Nevertheless, they denied any formal connection with the ANA.

The BMA's objection to the women's lodge was that it ignored their demand for a 'minimum' annual subscription based on an average male wage, and did not impose an

\footnotetext{
${ }^{61}$ Annie Golding, 'The Women's ANA and the British Medical Association', Sydney Morning Herald, 21 October 1903, 4.

62 The WANA's recognition of women's lesser earning capacity certainly seemed to mark out this lodge from others. By comparison a study of friendly societies in New Zealand found that women's membership was 'never significant', which may simply have reflected the level of membership fees, and most women's inability to pay: Jennifer Carlyon, 'Friendly Societies, 1842-1938: Benefits of Membership', New Zealand Journal of History, 32, 2 (1998), 121-42: 126.

63 The clientele of most lodges and friendly societies were 'working men', whose subscriptions were designed to provide medical care for their families (except, as Gillespie pointed out, in obstetrics cases). See Green and Cromwell, op. cit. (note 57), 13, 50; Gillespie, op. cit. (note 16), 9.

64 'Australian Natives' Association for Women', Australasian Medical Gazette, XXII, March (1903), 118; Brian Fitzpatrick, Ninetieth Anniversary History of the Australian Natives' Association, 1871-1961 (Melbourne: ANA, 1961), 5-8.

65 [Editorial], 'The Australian Natives' Association and the Medical Profession of NSW', Australasian Medical Gazette, XX, August (1900), 335-37.

66 W.L. Mullen, 'The Question of Clubs, Dispensary, and Medical Aid Societies', Australasian Medical Gazette, XIV, July (1895), 285.

67 'Anti-Humbug', 'Letter to the Editor: The Australian Natives' Association', Australasian Medical Gazette, XIX, August (1900), 338.

68 'Women's Australian Natives' Association', op. cit. (note 58).
} 
upper income limit on members. In August 1903 the Sydney Morning Herald announced that the WANA had been blacklisted by the BMA as 'inimical to the medical profession'. Harriett Biffin, the report went on, had been officially requested to resign her position with the lodge. ${ }^{69}$ The specifically gendered issues of this case quickly resolved into the central point of dispute, formulated as the male BMA (NSW) against women doctors and their (female) patients. For Annie Golding, the sister of a WANA committee member, and a prominent women's rights activist, the matter was clear-cut: the BMA discriminated against women by insisting that women lodge-members pay the same dues expected of male members, despite the entrenched wage differential and the lack of 'family benefits' offered. Members of the WANA were, Golding declared, 'sweated girls, working long hours for a paltry pittance per week, in most cases receiving from one-third to a half of that received by men' - a point that the BMA chose not to address. ${ }^{70}$

The Golding sisters were equally adamant that the BMA was discriminating against women doctors. Arguing that the BMA's only motive for blacklisting the WANA was to curtail the activities of women doctors, Annie Golding equated the association with a 'combine or trust':

[It] practically controls the hospitals and other similar institutions, and though it denies that there is a bar in regard to sex, no woman has the faintest chance of being appointed on those staffs as medical advisers; and if one of them consents to act on the Women's ANA she will be socially and professionally boycotted.... This from a class that condemns trade-unionism. ${ }^{71}$

The BMA's public reaction gave short shrift to the notion of women's 'greater need'. ${ }^{72}$ According to George Hankins, branch secretary of the BMA (NSW), adequate access to free medical service for the 'poorer classes' already existed - and indeed was provided by women doctors themselves - so this new friendly society was clearly superfluous. ${ }^{73}$ The WANA was also misrepresenting itself, Hankins claimed, for its only purpose was to organise newly enfranchised women, and 'to throw in with the political advantages of membership cheap medical attendance'. ${ }^{74}$ The BMA (NSW) seemed equally incensed that women doctors alone were eligible for lodge positions. Far from supporting the WANA's objective of providing opportunities for women doctors, the BMA expressed indignation at the plan that 'only women doctors should be medical officers' of the lodge. Professional support for women's separatism was clearly constrained when it involved the apportioning of work. For while the BMA (NSW) recognised that 'the openings for appointments and practice... [for women] were more limited' than for men, that merely reflected the way of the world, and was no cause for giving women any 'special concessions'. ${ }^{75}$

Harriett Biffin decided to withdraw from the lodge as demanded by the BMA. However, this resignation suggests her awareness that the BMA's 'doctor blacklist' could damage her practice, rather than any change of heart over the WANA's objectives. ${ }^{76}$ Biffin had been an active member of the BMA (NSW) from the time of her election in 1901, at least as

69 'The Doctors and the Friendly Societies', Sydney Morning Herald, 24 August 1903, 6.

70 Annie Golding, 'Letter to the Editor: Women Doctors', Sydney Morning Herald, 25 August 1903, 8.

71 Golding, 'The Women's ANA', op. cit. (note 61), 4.

72 M. Beddie, 'Letter to the Editor', Sydney Morning Herald, 29 August 1903, 4.

73 George Hankins, 'Letter to the Editor', Sydney Morning Herald, 25 August 1903, 7.

74 [Editorial], 'Women Doctors', Australasian Medical Gazette, XXII, September (1903), 417.

75 Ibid., 417.

${ }^{76}$ Biffin was later a leader in establishing the women-only Rachel Forster Hospital in one of Sydney's most notorious inner-city slums. See Louella McCarthy, 'Women Doctors and a Sense of Place', Public History Review, 9 (2001), 45-60. 
can be measured by attendance at the monthly meetings. Her decision to resign from the WANA points to the recognition that professional networks and spheres of influence were important. By not alienating the BMA any further, Biffin could minimise the damage to her professional position, but this action left her with little expectation of the collegiality that was such an important element of society membership. To be weighed against this, however, is the fact that in 1904, the year following the WANA uproar, Biffin failed to renew her membership of the BMA.

Faint clues suggest that the struggle between Biffin and the BMA was perceived as a watershed by some of her female colleagues. Also in 1903, Ellen Wood, then in joint practice with Biffin, was expelled from the BMA (NSW), for uncannily similar reasons: her professional relationship with the Balmain United Friendly Society's Dispensary and Hospital. ${ }^{77}$ For the new medical women of Australia this was not an encouraging beginning to their involvement in their male-dominated professional society. While Ellen Wood eventually returned to the BMA in the 1920s, Harriett Biffin never again applied for membership.

As far as the BMA was concerned, Harriett Biffin's tactical withdrawal from the WANA represented a successful outcome, which achieved the association's aim of checking the threat posed by women 'willing to do any amount of work for the lowest price' (as Garrett Anderson had foretold). Yet they clearly felt no commensurate obligation to improve the 'more limited' opportunities that medical women were acknowledged to face. In essence Biffin's position with the WANA raised a twofold problem for the BMA. Overwhelmingly there was the reputed relationship between the WANA and the dreaded ANA. But the second difficulty was just as unsettling: the WANA was attracting members (ie. patients) among 'working' women, a change from the more usual provision of free or supplemental services to which women of this class were more often relegated. So strongly did the BMA feel about this issue that a new clause eventually entered their regulations: the remuneration for doctors in 'Juvenile Friendly Society Lodges and for Female Friendly Society Lodges shall be the same as that for Male Friendly Society Lodges'. ${ }^{78}$ The BMA's stand on this issue placed it on a strange parallel with the ANA itself, for this body, as Marian Quartly indicated, had since the 1880s refused women's requests for membership on the grounds that 'having different illnesses from men, they could not be included in the normal benefit tables'. ${ }^{79}$ There was to be no further attempt in this period to link women's incomes to lodge subscriptions, nor even to query the anomaly of the BMA's position of linking the subscription rates of women (and 'juveniles') to a male wage.

According to the BMA, women doctors themselves neither wanted nor appreciated the friendly societies' activities on their behalf. ${ }^{80}$ It justified this assertion by claiming that all the women doctors in Sydney 'are either members of the British Medical Association or

\footnotetext{
77 'Balmain', Sydney Morning Herald, 24 February 1903, 8; 'Friendly Societies and Doctors: The Trouble at Balmain', Sydney Morning Herald, 22 March 1904, 6; 'The Battle of the Clubs', Australasian Medical Gazette, XX February 1904, 86; 'The Doctors and the Hospital', Balmain and Western Suburbs Advertiser, 26 March $1904,4$.

78 Mitchell Library, AMA Collection, ML Mss 213/97 14/23, BMA Memorandum and Articles of Association, $1919,42$.

${ }^{79}$ Marian Quartly, 'Mothers and Fathers and Brothers and Sisters: The AWA and the ANA and Gendered Citizenship', Journal of Australian Studies, 37 (1993), spec. no., Women and the State: Australian Perspectives, ed. Renate Howe, 22-30: 24.

80 'Women Doctors: The ANA and the British Medical Association', Sydney Morning Herald, 1 September 1903, 9.
} 
are in sympathy with it' ${ }^{81}$ In fact fourteen women were practising in Sydney in 1903, the year of the WANA dispute, of whom eight - or just over half - were members of the BMA.

\section{The Rise and Fall of Women's Membership}

Indeed the proportion of women who were BMA members remained low up to the First World War. While around sixty-six per cent of all registered women doctors between 1892 and 1939 have been identified as members of the association at some point, there was considerable variation over time, both in their joining rates and in the duration of their membership. ${ }^{82}$ As a case study for this question we will examine membership of the BMA (NSW), since its early records are both intact and accessible. For the earliest women doctors in the 1890-1910 period, BMA membership seemed to hold little appeal, but subsequent developments were not uniform. There was quite a flood of women's applications during the 1910s, which then abated in the 1920s and 1930s when the proportion of women members dropped back again. Looking at how this pattern was played out across the entire period suggests that medical women may have been looking for something more from a professional society than was offered by the BMA.

Clearly some women - like their male counterparts - found the BMA useful, even if not all found it necessary for their practice. Women may also have found membership somewhat isolating: by 1905, out of the 502 members of the BMA (NSW), just 6 (1.2\%) were women. ${ }^{83}$ In 1906, almost fifteen years after women's membership had been allowed, out of a total membership of 1,353 across all the Australian branches (which then included New Zealand), a mere $23(1.7 \%)$ were women. Moreover those twenty-three represented about one quarter of all the medical women then estimated to be practising in Australia. ${ }^{84}$ In that same year Victoria had one of the largest clusters of female medical practitioners, yet none was a member of the BMA. ${ }^{85}$ In addition the medical women who did join the BMA were at times confronted by male colleagues who remained sceptical and somewhat antagonistic toward the whole 'experiment' of women doctors - a situation far from conducive to professional 'fellowship'.

Nevertheless, by 1910 women's rates of membership were rising: in NSW around fifty per cent of new graduates joined the association. Within the group of women who chose to become members, other patterns began to form. For those women whose careers might be considered the most successful, membership of the BMA was applied for early and retained longest. Several of these women received marks of professional recognition within the association as well, such as holding executive positions on the association's 'special sections' (harbingers of the specialist colleges). ${ }^{86}$

While women doctors often held concurrent membership of other medical societies, the 'successful' women's loyalty to the BMA indicated that they viewed it as a particularly important element in achieving career advancement. All the women who graduated before

81 'Women Doctors', Australasian Medical Gazette, XXII, September (1903), 417; 'Medical Notes', Australasian Medical Gazette, XXI, March (1903), 142.

82 Mitchell Library, AMA Collection, ML Mss 231/97 21/23, BMA Membership Ledgers, Vol. 2, 1901-1910.

${ }^{83}$ Mitchell Library, AMA Collection, ML Mss 213/97 21/23, BMA Membership Ledgers, Vol. 2, 1901-1910;

'List of Members of the BMA in the Various States of the Commonwealth and New Zealand', Australasian Medical Gazette, XXV, February (1906), 113-15.

${ }^{84}$ Hutton Neve, op. cit. (note 34), 163-5.

85 Ibid. See also 'List of Members of the BMA', op. cit. (note 83).

86 'BMA: Annual General Meeting, Special Sections', Medical Journal Australia, April (1924), 346; 'Notification of Meetings', Medical Journal Australia, August (1922), 201. 
1914 and joined the BMA were members for around ten years on average, whereas each of the 'successful' women had a membership record which stretched over twenty-five years or more. This distinctiveness also offers hints about the traits that helped doctors to succeed: for these women, competition with men was inherent in a successful medical career - although it could also be enjoyable for its own sake. Constance D'Arcy was one who seemed to impress male associates with her competitive quips. In the mid-1930s she was made a Dame of the British Empire for her medical work. 'This particularly pleased her,' recalled Douglas Miller, D'Arcy's colleague at St Vincent's (and later historian of the hospital), 'and she would chuckle over [receiving] an honour of higher order than the knighthood recently conferred on [the surgeon] John McKelvey. ${ }^{87}$

Ambition may have been a significant issue in women's long-term membership of the BMA, although the role of marriage and maternity also needs to be taken into account. Overall, eleven of the nineteen women who joined between 1901 and 1910 retired their membership early. Two or three of these women apparently resigned for reason of marriage or maternity. ${ }^{88}$ Since the overall marriage rate for Australian women doctors during this early period stood at around forty per cent, clearly not all medical women felt constrained to 'retire' when they married, either from the BMA or from practice. By way of comparison, it appears that women who were not BMA members during this initial phase 'retired on marriage' at an equivalent rate to members. These levels of commitment to professional association membership and unbroken practice stand in contrast to prevailing societal norms, and to claims made at the time (and subsequently) that training women doctors was likely to be a drain on limited educational resources. By contrast, six of the eleven NSW women who resigned their membership (55\%) did so in order to travel. Agnes Bennett was one, deciding at this point to emigrate to New Zealand. Her friend and later compatriot, Kate Hogg, roamed more widely, obtaining her MD from Edinburgh in 1909 and then spending some years in various European cities. Of the remaining two, Ellen Wood was expelled (as we have seen), and Margaret White died young.

The BMA's appeal for women reached its greatest strength in the period between 1911 and 1920 when the proportion of women who joined the BMA peaked at almost ninety-four per cent of those who registered for practice. This figure reflected the wider membership: in its Council's Annual Report for 1921, the BMA proudly pointed out that almost ninety per cent of the medical profession in Australia were members. ${ }^{89}$ Women's membership as a proportion of the number registered to practise was thus reaching equivalence with men's. Women's high membership levels during the war years were rapidly reversed thereafter, however, a trend which ran counter to the increasing number of medical women who registered. During the 1920s, registrations by women reached unprecedented levels, but the ten-year period from 1921 to 1930 saw the proportion of women BMA members drop to just sixty-seven per cent. These figures continued to fall through the 1930 s.

Looking only at joining rates, however, leaves retention rates invisible. In other words, were women leaving (or not joining) the association because they were no longer in

\footnotetext{
${ }^{87}$ Douglas Miller, Earliest Days: A Story of St Vincent's Hospital, Sydney (Sydney: Angus \& Robertson, 1969), 56. McKelvey had received a KB in the 1933 New Year's Honours: Sydney Morning Herald, 2 January 1933, 4. See also Louella McCarthy, 'Constance D’Arcy', Dictionary of Medical Biography (Westport, CT: Greenwood Press, 2007), 398-9.

${ }^{88}$ McCarthy, op. cit. (note 60), 346.

89 'Annual Report of Council', Medical Journal Australia, July (1921), 9.
} 
practice? To solve this problem, it is necessary to compare the proportion of women members with the number of women in active practice at particular times. However, this ambition is made difficult by the lack of BMA membership ledgers for the period between 1932 and 1939. Joining rates for this period are available as these were published as part of the branch's monthly meeting minutes in the Medical Journal of Australia. A member's resignation was not published, however, so it is difficult to be precise about the duration of membership. Knox's Medical Directory for Australia, published during the 1930s provided information about BMA membership and has been used wherever possible.

The post-war decline in women's participation in the BMA is more dramatic in this second representation: membership rates for women in active practice rose from $8 \%$ in 1900 to over $70 \%$ in 1915, and then dropped back to less than $50 \%$ by 1935 . Why did women's membership rates rise and then fall across this period? Several alternative explanations are possible. The rise in women's participation during the war years is particularly noticeable. The outbreak of war may have generated sentiments of professional solidarity between women and men, feelings that had been absent (or at least tenuous) hitherto. For the majority of new members were women with years of medical practice history, but in the lead-up to war and during its opening phases, decided to join. The difference between the two rates mentioned above is thus explained by this 'catch-up' in women's membership during this period.

By 1920 the decline had already begun to set in. The female membership had also become slightly younger. Perhaps the implication behind the growth of women's membership during the war years was less a positive drawing together of men and women doctors, but rather that with so many male doctors away at war, women found BMA meetings less overwhelmingly masculine. The dramatic post-war increase in the number of graduating men many of whom were returned servicemen - and comparable increases in male BMA membership (in NSW for example, from 970 in 1915 to 1,600 by 1920) may have discouraged some women from joining.

The continuing decline after 1920 may also indicate rising numbers of women who were more inclined than their forebears to marry and retire, either at marriage or when children arrived. So how do such rates compare? Of the 146 women who registered in NSW between 1925 and 1939, sixty-four (or 44 per cent) married. Comparatively speaking then, marriage rates had not significantly changed from the pre-war period, and almost half (47 per cent) of the BMA's married women members in NSW continued in practice.

The BMA seemed to be aware that it was losing its attraction for women, and in 1923 introduced a new subscription arrangement for married medical couples, at a reduced 'joint membership' rate - perhaps in recognition of medical women's propensity to marry other doctors. The subscription rates for membership over the preceding years had some elements of variability: in 1919, for example, young members 'within three years of medical registration' paid just three guineas, compared to the full membership rate of five guineas. Members older than seventy and doctors employed by the public service also enjoyed reduced subscriptions. ${ }^{90}$ The married rate, on the other hand, was the only subscription variant directly related to gender. The BMA's Council passed the motion without dissent, allowing a married couple to join by paying one full fee and one discounted fee. ${ }^{91}$

\footnotetext{
${ }^{90}$ Mitchell Library, AMA Collection, ML Mss 213/97 14/23, BMA Memorandum and Articles of Association, 1919.

91 'NSW Branch of the BMA. Extraordinary Meeting, 23 March 1923', Medical Journal Australia, April (1923), 390.
} 


\section{Women's Experiences of BMA Membership}

One strong resemblance between this second generation of medical women - those who graduated and registered after the First World War - and their earlier colleagues is found in the correlation between membership and professional status. Women whose medical work can be identified stretching over long periods, or those who enjoyed marked 'success', were also long-term members of the BMA with unbroken records of membership. If some women saw membership of the BMA as an important part of a successful career, it remains unclear whether this reflected a greater identification with the association as a putatively ungendered social and professional grouping.

Yet for women who felt confident in such settings, the BMA scientific meetings could be an opportunity to challenge professional ideas. In a paper presented in 1927, for example, Constance D'Arcy at the age of forty-eight seemed to take some pleasure in 'correcting' a number of prevailing 'misconceptions' about the menopause. After a somewhat lengthy discussion of the various glands and secretions involved in 'the change', D'Arcy raised the claim that women's major concern during the menopause was an unreliable memory. She breezily summarised: 'Women who have found the acquisition of foreign languages easy, and who have made a study of a new language every five years or so, find they can no longer.' D'Arcy was convinced that this disability was temporary, citing the example of Queen Victoria, 'who acquired a new language - Hindustani - at seventy-five years'. She concluded her paper by reversing the preconception of 'man' as the pinnacle of civilisation to which all aspired, while simultaneously underscoring men's privileged position. As far as Constance D'Arcy was concerned, 'although women will cry out about the injustice suffered by their sex and that man owns the earth, the greatest possible tragedy that the mind of woman could conceive would be that she should be converted into a man' ${ }^{92}$

Outside these rare moments, meetings of the BMA (NSW) remained overwhelmingly masculine. Women's marginalisation within professional associations limits their ability to participate in a variety of ways including, as Paul Atkinson and Sara Delamont indicated, 'informal communications, collaborative work, and co-authorship' ${ }^{93}$ This can be seen in operation during the 'open discussion' of papers, whose contributions were frequently reprinted in the BMA's professional journal. Only a few women ever appeared in these reports, but these few women appeared on many occasions. Mary Booth, Lucy Gullett, Constance D'Arcy and Margaret Harper were among the most regular contributors, at times criticising issues raised at professional gatherings. At one such meeting in 1916 Lucy Gullett chose to reply at length on a subject that may have seemed a particularly masculine affair: the battlefield. In her impromptu response to a male colleague's jaundiced opinions of the Australian war effort, Gullett 'enthusiastically' discussed some of the 'wonderful work she had seen done at the front'. Ranging across topics such as the different types of wound inflicted by bullets, through to hospital organisation and the wonders of the new steel helmets, she gave every indication of a woman who felt comfortable amongst her professional peers. ${ }^{94}$

The words of these prominent women stand out by their rarity, however. Participation was an essential component in professional advancement, and as Regina Morantz-Sanchez

\footnotetext{
92 Constance D'Arcy, 'Nervous Disturbances in the Natural and Artificial Menopause', Medical Journal Australia, August (1927), 291-4: 294.

93 Atkinson and Delamont, op. cit. (note 20), 101.

94 'Meeting of the NSW Branch of the BMA, 15 December 1916', Medical Journal Australia, January (1917), 89.
} 
emphasised for American women doctors, 'publishing provided the most effective avenue for attaining this goal'. ${ }^{95}$ These 'valued professional credentials', as Charles Rosenberg termed them, were difficult for most women to obtain. ${ }^{96}$ And while the starkness of the gender disproportion in the 1890s had diminished in the post-war period, the BMA's membership continued to be dominated by men. By 1915, for example, women's representation had doubled, rising to $3.5 \%$ of the total, and then rose again to $5.4 \%$ by $1926 .^{97}$ Despite the slow increase in women's presence, they remained a tiny minority.

Even for those women members who might be defined as having leadership positions based on their activities within the association, a slightly different image is offered by looking at the roles they were assigned during important public events. In 1929 for instance, the association's pre-eminent gathering, the Australasian Medical Congress was held in Sydney. Just one woman was elected to a position on the executive committee of congress, Constance D' Arcy. Furthermore, her position was described as 'representing the medical women', not the profession in general. Only two other women held positions on the various sub-committees for this congress: Lucy Gullett on the 'entertainment committee', and Mary Burfitt on the 'soiree sub-committee'. ${ }^{98}$ So women within the BMA, even those 'loyal' members who held prestigious consultants' positions, faced marginalisation within their professional association. It seems the BMA did not offer women sufficient scope to benefit equally from their membership of the association.

Perhaps even more displeasing were the times when women's presence as members of the association was either forgotten or denied. The arrangements to celebrate the fiftieth anniversary of the BMA (NSW) in 1930 was indicative. Social events of this kind were designed both to generate camaraderie among colleagues and to foster allegiance to the association. Professional organisations have been claimed to fulfil particularly important purposes for the medical profession, to the extent, as Ellen More argued, of eventually coming to 'replace the local community as the doctor's primary source of socio-cultural values'. ${ }^{99}$ Planning for the BMA's festivities in Sydney, however, suggests that women's roles within their association were not seen in these ways.

The site chosen for the branch's 'jubilee' celebrations was the University Club in Phillip Street, Sydney. As a great many medical practitioners were members of this club, it may have been considered an obvious place to hold such an occasion. ${ }^{100}$ It was planned from the outset as a 'gala' event, and the invitation list was designed to parade the significance of the profession and its association. After negotiating the menu and wines for dinner, the organising committee issued invitations to the BMA's membership, and to the special guests who included the governor, the state premier and minister for health, the chancellor and vice-chancellor of the University of Sydney, and the city's lord mayor.

The first indication that plans had gone awry was in September, a mere fortnight before the grand dinner. Despite the large medical membership of the University Club,

\footnotetext{
95 Regina Morantz-Sanchez, 'Making it in a Man's World: The Late-Nineteenth Century Surgical Career of Mary Amanda Dixon Jones', Bulletin of the History of Medicine, 69, 4 (1995), 556.

96 Charles E. Rosenberg, 'Inward Vision and Outward Glance: The Shaping of the American Hospital, 1880 1914', Bulletin of the History of Medicine, 53 (1979), 352.

${ }^{97}$ As a comparison, women represented about $7 \%$ of the profession in NSW by 1921: 'British Medical Association, List of Members, 1921', Medical Journal Australia, 5 February (1921), Supplement, iii-vii.

98 Australasian Medical Congress (University of Sydney), Official Handbook (Sydney: BMA, 1929).

${ }^{99}$ More, op. cit. (note 8), 606.

${ }^{100}$ State Library of New South Wales, Pamphlet File, University Club, List of Members, 1936 (Sydney, 1936); By-Laws and Regulations of the University Club (Sydney, 1909, 1912, 1936, 1951).
} 
it seems that the club's prohibition on women's admission had been entirely overlooked. In a letter to the club's board of directors, the BMA secretary inquired in embarrassed fashion whether the club might make an exception to this policy. Despite the fact that the 'jubilee' was considered a major milestone in the association's history, the BMA offered a rather feeble explanation for this oversight, claiming that its organiser, F. Brown Craig, 'had not had it in his mind that women members of the Association might wish to attend'. ${ }^{101}$ But not even the collective authority of the BMA could sway the club's management, who regretfully declined the request to admit women. ${ }^{102}$ This incident was by no means an isolated one. Three years later in 1933 an identical 'oversight' marred the annual 'Reunion Week' dinner of the Royal Prince Alfred Hospital Resident and ExResident Medical Officers' Association. Even though the occasion was to incorporate the association's AGM, the organising committee was loath to cancel, so both the function and the meeting went ahead without any women present - although the association expressed its 'hope' that such an occurrence could be 'avoided' in the future. ${ }^{103}$ By contrast, the BMA (NSW) in 1930 had at least recognised the gracelessness of suggesting that women members would be barred from attending. A very hurried reorganisation ensued, and the event was moved from the University Club to the David Jones Auditorium, with an equally speedy reissuing of the members' 'admission cards'.

\section{Conclusion}

Examining the gendered 'fractures' and connections in the history of the BMA in Australia (as Kristin Barker recommended) allows a clear view of some of the driving issues for this particular medical society, and by extension the nature of professional associations more generally. ${ }^{104}$ In line with the arguments of a number of historians, it can be seen that professional societies generate and wield considerable social and cultural authority. The BMA's use of this authority had a significant but also perplexing influence on the 'woman doctor question', particularly in Australia. To an extent prominent men in the BMA used their professional standing to silence male dissent over women's membership, and in the process legitimated women's professional presence - if not their general acceptance. In doing so, however, the men of the BMA effectively silenced women and their attempts to combat the gendered, culturally determined impediments they faced in their medical practice.

Notwithstanding their role in facilitating women's membership, the Australian BMA shared with many Australian cultural institutions, a deeply masculinist ethos. For women, as for men, BMA membership could mean a springboard for professional 'success'. This was true for women such as Constance D'Arcy. For others, however, the price of acceptance was high, as the case of Harriett Biffin demonstrated, requiring her to sacrifice (at least in the short term) both a paying position and the feminist ideals that underpinned it.

The Australian BMA's determination to enable women's membership can therefore be reconciled with another of their dominant characteristics: a preoccupation with working

\footnotetext{
101 Mitchell Library, AMA Collection, ML Mss 231/97 6/23, [Letter], BMA (NSW), Hon. Secretary to Board of Directors (University Club), 12 September 1930.

102 Mitchell Library, AMA Collection, ML Mss 231/97 6/23, [Letter], Claude Pain to Dr F. Brown Craig, 15 September 1930.

${ }^{103}$ Royal Prince Alfred Hospital Resident and Ex-Resident Association, Year Book (Sydney, 1933), 181.

${ }^{104}$ Barker, op. cit. (note 27).
} 
conditions. In the country that was (and is) often hailed as a home of industrial unionism, this zealotry carries historical resonances, despite its being at the expense (rather than in support) of the working classes. The reiteration by the BMA in Australia that its role was to ensure that medical practitioners worked together to protect their incomes led to unexpected outcomes such as an insistence on women's membership. Yet even in the post1918 world the BMA in Australia was incapable of recognising and accommodating the gender disparities that afflicted women in the wider workforce.

In general terms, we can say that the newly consolidated professional bodies of the late nineteenth century did not keep their promise for most women. Instead of collegiality they offered recurrent examples of animosity or ostracism; rather than providing professional networks and support, they offered difficult choices between capitulation and exclusion. Yet women recognised, as did men, that associations offered intrinsic professional value, as witnessed by those 'professionally successful' women whose membership was long and unbroken, despite missing out on some of the elements that were available to male colleagues. Women therefore, both in Australia and elsewhere, sought these missing elements from different places. Women turned, reflecting in some respects the male model, to separatist organisations: women-only professional bodies that gave them collegiality and professional networks. These were associations where women's work and interests could be at the heart of the organisation rather than at its peripheries. In Australia these took the form of state-based organisations that agreed collectively to form the Australian Federation of Medical Women in 1929. ${ }^{105}$

The fact that many of these 'separatist', women-only professional medical organisations continue to operate today, despite the significant gains women have made in the profession of medicine, attests to the longevity of their value for women in the face of the equivalent longevity of entrenched gender values demonstrated by 'mainstream' medical societies.

105 Sandford Morgan, op. cit. (note 34). 